
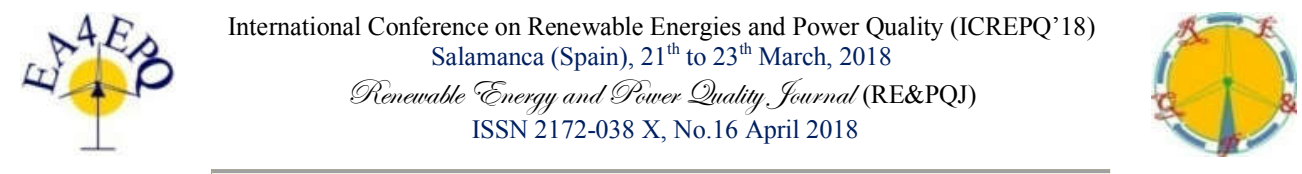

\title{
The Use of Solar Energy in Brazilian Residences
}

\author{
E. F. Nogueira ${ }^{1}$, G. Garcia ${ }^{1}$, R. C. Betini ${ }^{1}$, P. C. Fritzen ${ }^{1}$ \\ ${ }^{1}$ Department of Electrical Engineering \\ Federal University of Technology - Paraná \\ Campus Curitiba - Av. Sete de Setembro, 3165, Paraná (Brazil) \\ Phone/Fax number:+0055 41.9631.6699, e-mail: \\ contato.leoo@hotmail.com, gabi_garcia1991@hotmail.com, betini@utfpr.edu.br, pcfritzen@gmail.com
}

\begin{abstract}
The present article evaluates the economic viability of the application of solar energy for electric power generation via the use of photovoltaic systems in a residential consumption unit in the city of Curitiba, State of Paraná, Brazil. Since the energy from the sun is abundant, clean and renewable and has the potential to compete in productivity and profitability, it is of great interest to evaluate the applicability of these systems in homes and not only in industrial parks. A residence with the determined consumption profile was chosen to carry out the case study through simulations with the HomerPro software. After analyzing the data, the photovoltaic potential of the State of Paraná was estimated, in order to evaluate the use of photovoltaic generation in the State energy matrix.
\end{abstract}

\section{Key words}

Photovoltaic Systems, Solar Energy, Renewable Energy, Photovoltaic Power Generation.

\section{Introduction}

The introduction of electric power as the driving force of machines in the industrial revolution has made technological innovations more and more tied to electricity. This fact made economic growth dependent on this form of energy.

The degradation of the environment and the prediction of the shortage of fossil fuels in the near future show the importance of the generation of energy with the minimum of environmental impact. This fact highlights the importance of inserting different energy sources into the national electric matrix.

Although the State of Paraná has a great hydraulic potential, the estimate is that around $70 \%$ of this potential has already been explored. This data shows the difficulty of expansion in this sector and the need for investments in other sources of electricity generation. Viable alternatives would be renewable sources such as wind and solar [1,2].
In this article a case study was made using the HomerPro software [3], in which a residence that represents the great majority of the residential consumers in the city of Curitiba, state of Paraná, was selected to carry out simulations in case the residents adhere to the photovoltaic generation system connected to the power distribution network. It was possible to estimate values of the photovoltaic potential of the State of Paraná after obtaining the data of generation of energy through the simulations with the software. And a study was made where it is possible to estimate values of the photovoltaic potential of the State of Paraná in case the photovoltaic generation was disseminated in the State and became more representative in its energy matrix.

\section{Case Study}

With the objective of analyzing the economic viability of the installation of a photovoltaic system, a residence located in the neighborhood called Santa Felicidade, belonging to the Northwest region of Curitiba was selected.

The chosen residence is typical of a middle-class family of four. It has three bedrooms, two bathrooms, a living room and a kitchen, totaling no more than $70 \mathrm{~m}^{2}$ of built area.

Both showers are electric, that is, large consumers of energy. The residents of the house stay outside during the day. Therefore the energy consumption peaks are concentrated between 7 and 8 o'clock in the morning and from 6 to 10 o'clock in the evening.

The electricity bill was obtained so that the monthly consumption analysis was performed. Table I shows the monthly consumption of energy of the residence for one year. 
Table I. - Monthly consumption of electricity.

\begin{tabular}{|c|c|}
\hline Month/Year & Consumption in $\mathrm{kWh}$ \\
\hline $10 / 16$ & 307 \\
\hline $09 / 16$ & 351 \\
\hline $08 / 16$ & 297 \\
\hline $07 / 16$ & 362 \\
\hline $06 / 16$ & 295 \\
\hline $05 / 16$ & 275 \\
\hline $04 / 16$ & 320 \\
\hline $03 / 16$ & 277 \\
\hline $02 / 16$ & 279 \\
\hline $01 / 16$ & 295 \\
\hline $12 / 15$ & 293 \\
\hline $11 / 15$ & 278 \\
\hline & Average $=302$ \\
\hline
\end{tabular}

Source: Prepared by the authors.

A. Analysis and Estimation of the Photovoltaic Potential of Paraná

After presenting the economic viability for the installation of photovoltaic systems in homes of up to $70 \mathrm{~m}^{2}$, a deeper analysis of the implantation of these systems can be made, with the objective of ascertaining the potential of photovoltaic generation in an estimative way in the State of Paraná in its totality and look for alternatives from the possibility of expanding the photovoltaic market and this market to assume a more important role in the state energy matrix.

The last energy balance of Paraná made available by Companhia Paranaense de Energia is 2010 (base year 2009) and through it it is possible to observe that the state's most significant energy source is hydroelectric power, followed by energy generated through cane products, which grew significantly between 2005 and 2010, as shown in Table II.

\section{B. Simulation with HomerPro Software}

HomerPro software can be downloaded from the Homer Energy website [3]. First it is recommended that a test with the demo version that has a duration of 30 days be made and after exploring the software, it becomes simpler to choose the most appropriate licensing. In this study was used the test version of the program, with a duration of one month.

HomerPro aims to model power generation systems with renewable and non-renewable energy generation stations. The program brings a variety of more detailed elements to insert into the power system and thus get deeper and accurate results.

After obtaining the average energy consumption of the residence, it was possible to carry out simulations in order to analyze the radiation levels absorbed by the selected solar modules. The simulation model allow to define the load demanded by the residents of the residence, the cost of operating the system, how much energy was generated by the photovoltaic system, as well as how much surplus energy is generated and returned to the distribution network.
C. Analysis and Estimation of the Photovoltaic Potential of Paraná

This analysis allows searching alternatives for the possibilities of expanding the use of photovoltaic generation so that it can assume a more important role in the state energy matrix.

The last energy balance of Paraná made available by Companhia Paranaense de Energia is 2010 (base year 2009) and through it, it is possible to observe that the State's most significant energy source is hydro, followed by energy generated through sugar cane products, as shown in Table II.

Table II. - Evolution of the Paraná energy production.

\begin{tabular}{|l|c|c|c|c|c|}
\hline $\begin{array}{c}\text { Consumption } \\
\text { (GWh) }\end{array}$ & $\mathbf{2 0 0 5}$ & $\mathbf{2 0 0 6}$ & $\mathbf{2 0 0 7}$ & $\mathbf{2 0 0 8}$ & $\mathbf{2 0 0 9}$ \\
\hline Hydro Energy & 6.84 & 5.95 & 6.95 & 7.45 & 7.06 \\
\hline Cane Products & 1.96 & 2.44 & 3.17 & 3.65 & 3.74 \\
\hline Firewood & 1.51 & 1.61 & 1.70 & 1.77 & 1.67 \\
\hline Wood Residues & 1.22 & 1.29 & 1.32 & 1.57 & 1.62 \\
\hline Other Sources & 0.26 & 0.25 & 0.25 & 0.33 & 0.35 \\
\hline Shale & 0.18 & 0.22 & 0.21 & 0.15 & 0.18 \\
\hline Oil & 0.37 & 0.24 & 0.20 & 0.15 & 0.00 \\
\hline Mineral Coal & 0.45 & 0.45 & 0.47 & 0.52 & 0.53 \\
\hline Total & $\mathbf{1 2 . 3 9}$ & $\mathbf{1 2 . 0 3}$ & $\mathbf{1 3 . 8 5}$ & $\mathbf{1 5 . 1 1}$ & $\mathbf{1 4 . 6 7}$ \\
\hline
\end{tabular}

Source: Data extracted from [8].

Table III presents a comparison of electricity consumption in the State of Paraná between the years 2010 and 2014. It discriminates how much each service sector consumes individually of energy.

Table III shows that the total consumption of energy in the State increased by about 20\% between 2010 and 2014 . The largest energy consumer is the industrial sector, followed by residential and commercial.

Table III. - Power consumption of Paraná.

\begin{tabular}{|l|c|c|c|c|c|}
\hline $\begin{array}{c}\text { Consumption } \\
\text { (GWh) }\end{array}$ & $\mathbf{2 0 1 0}$ & $\mathbf{2 0 1 1}$ & $\mathbf{2 0 1 2}$ & $\mathbf{2 0 1 3}$ & $\mathbf{2 0 1 4}$ \\
\hline Residential & 6.02 & 6.32 & 6.65 & 6.99 & 7.36 \\
\hline Industrial & 10.65 & 11.06 & 11.36 & 11.88 & 12.11 \\
\hline Commercial & 4.57 & 4.91 & 5.26 & 5.49 & 5.96 \\
\hline Rural & 1.80 & 1.90 & 2.06 & 2.12 & 2.29 \\
\hline Public Sector & 0.63 & 0.65 & 0.67 & 0.68 & 0.71 \\
\hline $\begin{array}{l}\text { Street } \\
\text { lighting }\end{array}$ & 0.83 & 0.86 & 0.89 & 0.94 & 0.98 \\
\hline Public Services & 0.63 & 0.66 & 0.69 & 0.70 & 0.74 \\
\hline Others & 0.23 & 0.21 & 0.20 & 0.23 & 0.25 \\
\hline Total(GWh) & $\mathbf{2 5 . 3 6}$ & $\mathbf{2 6 . 5 5}$ & $\mathbf{2 7 . 7 9}$ & $\mathbf{2 9 . 0 3}$ & $\mathbf{3 0 . 3 9}$ \\
\hline Source: Prepared
\end{tabular}

Source: Prepared by the authors based on data extracted from [4].

According to the data presented in the demographic census conducted by IBGE, Paraná has 3,298,304 permanent households. 
The IBGE divides these households by monthly nominal income classes. Among them is the class of households with income of two to five minimum wages per month (from U \$ 568.00 / month to U \$ 1,420.00 / month), totaling 1,310,059 households [5].

This class was chosen as the focus of the analysis because it is the most expressive numerically and because it has characteristics similar to the one studied in this article. Also this class of domicile has a favorable monthly income for a possible implantation of photovoltaic modules.

\section{Results}

\subsection{Cost of Operation and Installation}

Through a market research for the necessary equipment was designed a photovoltaic system that surpassed the energy demand of the residence, partially, so that the tariff of the energy generated by the system was the most advantageous possible.

The photovoltaic system modulated by the software has eight solar modules with power of $2 \mathrm{kWp}$ and an inverter of $2.5 \mathrm{~kW}$. The cost of each solar panel would be $\mathrm{R} \$$ $1,000.00$ each $(\mathrm{U} \$ 1.00=\mathrm{R} \$ 3.30$ in September 2017), totaling R \$ 8,000.00.

The inverter is priced at $\mathrm{R} \$ 5,000.00$ according to market research. It is important to point out that the projected system has a 25-year useful life, without the need to change the solar panels. The inverter needs to be changed every 10 years, so two exchanges will be necessary during this lifetime of the photovoltaic system, adding another $\mathrm{R} \$ 10,000.00$ to the budget.

A cost of maintenance of solar modules of $\mathrm{R} \$ 2,500.00$ and inverters of $\mathrm{R} \$ 1,250.00$ during the 25 years of life of the system is estimated. Therefore, the total maintenance value would be $\mathrm{R} \$ 3,750.00$.

Table IV shows the total cost of the system, without taking into account possible works required for the installation of the system, as well as the equipment required by the Local Energy Concessionaire for connection to the distribution network.

Table IV. - Budget of the photovoltaic system.

\begin{tabular}{|l|l|l|}
\cline { 2 - 3 } \multicolumn{1}{c|}{} & \multicolumn{1}{c|}{ Quantity } & \multicolumn{1}{c|}{ Value (R\$) } \\
\hline Solar Module & 8 & $1,000.00($ each) \\
\hline Inverter & 1 & $5,000.00$ \\
\hline Inverter & 2 & $5,000.00($ each) \\
\hline Maintenance & - & $3,750.00$ \\
\hline & TOTAL & $\mathbf{R \$ ~ 2 6 , 7 5 0 . 0 0}$ \\
\cline { 2 - 3 } & &
\end{tabular}

Source: Prepared by the authors based on data extracted from [3].

\subsection{Annual Economy and Estimation of the Time of Return of the Investment}

To calculate the savings that the system generated when installed, it is calculated the avoided cost, that is, the sum of the electric bills that will not be paid over the years for having the photovoltaic system installed, considering the loss of efficiency of the photovoltaic module of $0.65 \%$ per year.

The costs of the tariff are based on the tariff applied by Copel (Local Energy Concessionaire) and a readjustment estimate of $8.5 \%$ annually attributed to the value of the electricity tariff. These values are shown in Table V.

For the purposes of calculating the return on investment, the total investment of the photovoltaic system implantation mentioned in section 3.1 and the economy in years obtained by the photovoltaic generation should be considered.

With this information it is possible to estimate the return time of the investment in years. For the system studied, the time of return is estimated to be little more than eight years, as observed in Table V, in the year 2024.

Table V. - Annual savings with the implantation of the photovoltaic system and estimation of the time of return of the investment.

\begin{tabular}{|l|c|c|c|}
\hline Year & $\begin{array}{l}\text { PV generation in } \\
\text { kWh / year (with a } \\
\text { loss of efficiency of } \\
\text { 0.65\% / year) }\end{array}$ & $\begin{array}{l}\text { Cost rate } \\
\text { (readjust } \\
\mathbf{8 . 5 \%} \text { / year) }\end{array}$ & $\begin{array}{c}\text { Annual } \\
\text { Savings } \\
\text { (R \$) }\end{array}$ \\
\hline 2016 & 3,639 & 0.56 & 2033.00 \\
\hline 2017 & $3,615.34$ & 0.61 & 2191.47 \\
\hline 2018 & $3,591.84$ & 0.66 & 2362.29 \\
\hline 2019 & $3,568.49$ & 0.71 & 2546.42 \\
\hline 2020 & $3,545.30$ & 0.77 & 2744.91 \\
\hline 2021 & $3,522.26$ & 0.84 & 2958.87 \\
\hline 2022 & $3,499.36$ & 0.91 & 3189.50 \\
\hline 2023 & $3,476.61$ & 0.99 & 3438.12 \\
\hline $\mathbf{2 0 2 4}$ & $\mathbf{3 , 4 5 4 . 0 2}$ & $\mathbf{1 . 0 7}$ & $\mathbf{3 7 0 6 . 1 1}$ \\
\hline 2025 & $3,431.57$ & 1.16 & 3994.99 \\
\hline 2030 & $3,321.48$ & 1.75 & 5814.39 \\
\hline 2040 & $3,111.79$ & 3.96 & 12316.29 \\
\hline 2041 & $3,091.56$ & 4.29 & 13276.32 \\
\hline & & $\begin{array}{c}\text { Total } \\
\text { Savings }\end{array}$ & $\mathbf{1 5 7 , 5 1 8 . 5 1}$ \\
\cline { 2 - 4 } & &
\end{tabular}

Source: Prepared by the authors based on data extracted from [3].

\subsection{Estimated Results of the Photovoltaic Potential of the State of Paraná}

With the IBGE data presented previously, it is known that the selected consumer class has about 1,310,059 households in Paraná. 
If all households, in the class chosen for the study, had their own photovoltaic systems connected to the distribution network, generating around $250 \mathrm{kWh} / \mathrm{month}$ per household, the total generated would be around 3.0 MWh/year per household. And Paraná would be producing around 3,930.18 $\mathrm{MWh} /$ year through photovoltaic systems.

The State of Paraná produced 1,002,674,506 MWh of electricity in the year 2015 [6]. Taking into account that the city of Curitiba consumes around 4,951,764 MWh / year [7], this estimated photovoltaic generation would be able to supply almost $80 \%$ of the capital of Paraná.

According to Table III, the electricity consumption in households in Paraná in 2014 was 7,363 GWh. Therefore, if the households of the chosen class joined the photovoltaic generation, this model of micro generation would be able to supply more than $53 \%$ of the homes of Paraná.

These numbers are just estimates, they do not exactly represent the potential of photovoltaic generation in Paraná, but they serve as the basis for an analysis of how representative photovoltaic generation can be for the State.

\subsection{Perspectives}

According to the Energy Research Company-EPE [4], the electricity consumption projection of the grid in the country for a horizon up to 2020 is approximately 630 TWh.

The residential class will represent $28.7 \%$ of the total with a growth of $3.8 \%$ annually, and the commercial segment $20.3 \%$ with an annual growth of $4.4 \%$.

For the same horizon, EPE projected a growth of 5 million in the number of permanent private households totaling about 71 million households in the country by the end of 2020 .

Therefore, the continuous growth of national per capita income together with the per capita consumption of electricity would be a point of great importance in the present study.

It is notable that the growth in the demand for electric power, the increase in the number of private residences and the increase of the national income per capita provide a favorable horizon for the investment in renewable energy sources in the country.

\section{Discussions}

Photovoltaic generation is still considered an expensive energy source in Brazil due to the price of the initial investment. Otherwise, as demonstrated in sections 3.1 and 3.2 , in the medium and long term it brings a very satisfactory return.

Photovoltaic generation is still not widespread in the Brazilian market. So in most cases the population has the concept of micro generation only as a utopia or that only people with great purchasing power can enjoy.

But according to the researches and investigations carried out and presented in the present work, it is clear that solar energy should occupy an important position in the energy matrix not only in the State of Paraná, but also in Brazil.

The existence of financing programs for the population interested in having their micro generation plants would be of great importance and stimulate the use of the micro generation process.

Today, banks such as Caixa Econômica Federal, BNDES and Santander, for example, have loan and installment programs for photovoltaic projects.

Some States of Brazil have programs and public policies focused on micro-generation. An example is the State of São Paulo, where the "Green Economy Financing Line" was created, which aims to reduce the State's $\mathrm{CO}_{2}$ emissions by $20 \%$ by 2020 .

This program also finances solar generation projects. In this way, the creation of a federal program to introduce photovoltaic energy not only in homes but also in companies would bring prosperity to the country.

If Brazil were to use photovoltaic energy on a larger scale, this action would increase the incentive for the national production of photovoltaic modules and make them cheaper. Nowadays, to a great extent, these modules are imported and this makes the total investment in this type of system more expensive.

In the case of the State of Paraná, if the previously mentioned households actually adhered to the photovoltaic generation, the state's energy and economic scenario would be altered.

With micro generation in homes, the demand for energy generated by other sources, which COPEL (Local Electricity Concessionaire) has control, would gradually become smaller. On the other hand, the energy injected into the grid by these micro generation plants would increase.

It would be providential to reduce the import of energy from other countries like Paraguay, for example. All this would contribute to the reduction of the cost of energy supplied by the concessionaire, which would cause a chain reaction to the State economy 


\section{CONCLUSION}

It is known that in a developing country, such as Brazil, there are areas to be prioritized, such as public health, education, basic sanitation, etc. But in relation to the micro generation it would be interesting to create governmental or even private initiative programs so that citizens can get to know the operation of photovoltaic systems connected to the grid. The advantages they provide and the difficulties that may exist.

As the case study focused on the city of Curitiba, analyzes and estimates were made for the State of Paraná. Numerically the calculated results prove that the photovoltaic energy can be one of the alternatives for the decentralization of the energy generation, collaborating for the diversification of the State energy matrix.

Although distributed generation benefits the power grid in many respects, it is necessary to take into account some aspects intrinsic to its use. Questions about the control, penetration level of photovoltaic generation facilities, the types of technologies used, the configuration of the distribution network itself, the network protections, the ability of the grid to operate with bidirectional power flows, among other aspects, can interfere in the integration of generating units.

Therefore, like most of the sources of electricity generation, photovoltaic generation also impacts the environment and the structure of the current distribution network used in Brazil.

The economic and environmental advantages make it attractive to increase the use of this energy source in the Brazilian energy matrix.

\section{References}

[1] BETINI, Roberto Cesar. Estratégias de Pesquisa e Desenvolvimento para a Redução do Uso de Combustíveis Fósseis. Energias Renováveis, Políticas Públicas e Planejamento Energético. Digital Edition, pg. 100-115, Curitiba, 2014. Available in: $<$ http://repositorio.utfpr.edu.br/jspui/bitstream/1/942/ 1/Energias\%20Renov\%C3\%A1veis_Pereira\%2C\%20 Thulio\%20C\%C3\%ADcero\%20Guimar\%C3\%A3es 2014.pdf>.

[2] TIEPOLO, Gerson. Estudo do potencial de Geração de energia elétrica através de sistemas fotovoltaicos conectados à rede no Estado do Paraná. Curitiba, SIBI/PUCPR, 2015.

[3] HOMER ENERGY - Software HomerPro. Available in: $<$ http://www.homerenergy.com/HOMER_pro.htm $>$.

[4] EPE - Empresa de pesquisa energética - Anuário Estatístico de Energia Elétrica, 2015. Available in: $<$ http://www.epe.gov.br/AnuarioEstatisticodeEnergia Eletrica/Anu\%C3\%A1rio\%20Estat $\%$ C3\%ADstico\%2 0de\%20Energia\%20El\%C3\%A9trica\%202015.xls>.

[5] IBGE - Censo Demográfico 2010: Rendimento Amostra (Paraná). Available in:
$<$ http://www.ibge.gov.br/estadosat/temas.php?sigla= pr\&tema $=$ censodemog2010_rend $>$.

[6] ONS - Boletim mensal de geração por estado. Available in: $<$ http://www.ons.org.br/resultados_operacao/boleti $\mathrm{m}$ mensal geracao estado/index.aspx $>$.

[7] IPARDES - Anuário Estatístico do Estado do Paraná Infraestrutura: energia, 2012. Available in: $<$ http://www.ipardes.pr.gov.br/anuario_2012/index.ht $\mathrm{ml}>$.

[8] COPEL - Balanço Energético. Available in: $<$ http://www.copel.com/hpcopel/root/nivel2.jsp?ende reco $=\% 2$ Fhpcopel $\% 2$ Froot $\% 2$ Fpagcopel $2 . n s f \% 2 F d o c$ s\%2FC824D47B05308F650325740C00438020>. 